\title{
Thallium Associated with Manganese Ore Tailings in a Deactivated Mine in the Western Region of Bahia, Brazil
}

\author{
Jorge Luís O. Santos, ${ }^{\oplus a}$ Giuliana M. G. Bueno, ${ }^{b}$ Eder L. M. Flores, ${ }^{c}$ Oldair D. Leite, ${ }^{\circledR *, c}$ \\ Clayton R. Janoni, ${ }^{d}$ Luis G. Carvalho ${ }^{e}$ and Ana Maria P. dos Santos ${ }^{f}$ \\ ${ }^{a}$ Centro Multidisciplinar de Bom Jesus da Lapa, Universidade Federal do Oeste da Bahia, \\ 47600-000 Bom Jesus da Lapa-BA, Brazil \\ ${ }^{b}$ Programa de Pós-Graduação em Ciências Ambientais, Universidade Federal do Oeste da Bahia, \\ 47808-021 Barreiras-BA, Brazil \\ 'Departamento de Química, Universidade Tecnológica Federal do Paraná, \\ 85884-000 Medianeira-PR, Brazil \\ ${ }^{d}$ Departamento de Geologia, Universidade Federal do Espírito Santo, \\ 29500-000 Alegre-ES, Brazil \\ ${ }^{e}$ Centro de Ciências Exatas e Tecnologia, Universidade Federal do Oeste da Bahia, \\ 47808-021 Barreiras-BA, Brazil
}

fInstituto de Química, Universidade Federal da Bahia, 40170-115 Salvador-BA, Brazil

\begin{abstract}
Thallium (Tl) is a rare metal with toxic effects notably harmful to human health and the environment. In this article, the natural occurrence of $\mathrm{Tl}$ was evaluated in a deactivated manganese mine located in the western region of Bahia, Brazil. The extraction procedure with aqua regia was used to dissolve the soil, sediment, and tailings samples. The Tl content was determined by differential pulse anodic stripping voltammetry (DPASV) and manganese (Mn) and iron (Fe) by flame atomic absorption spectroscopy (FAAS). The Tl levels ranged from 0.64 to $473 \mathrm{mg} \mathrm{kg}^{-1}$, triggering an alert since most of the samples (soil and sediment) analyzed presented $\mathrm{Tl}$ concentrations above $1.0 \mathrm{mg} \mathrm{kg}^{-1}$, recognized as the maximum limit recommended by environmental agencies in North America and Europe.
\end{abstract}

Keywords: environmental contamination, heavy metals, mineral, soil, mining-tailing

\section{Introduction}

Mining activities are known to have a high environmental impact. The extensive areas occupied by mines, as well as the steps involved in the process of extracting ores, cargo handling operations and the tailings generated, represent risks for populations in different regions of the planet. There is a vast amount of scientific studies ${ }^{1-12}$ regarding metals and metalloids effects on ecosystems, environmental, and human health.

In many deactivated mining areas, environmental monitoring studies were carried out, especially in order to access the potential for dispersion and geochemical mobility of metallic species, due to the inadequate management of tailings and residues in these sites., ${ }^{2,710,13-24}$

*e-mail: oldair.leite@gmail.com
Thallium (Tl) is a rare, non-essential, and high toxicity metal available in the environment for living beings. $3,8,9,25,26$ It overcomes the toxicity observed for elements such as arsenic, cadmium, lead and mercury, ${ }^{26,27}$ being lethal at doses in the range of 8 to $10 \mathrm{mg} \mathrm{kg}^{-1}$ for adult humans. ${ }^{28-30}$ It is considered a dangerous agent by the World Health Organization (WHO), ${ }^{31}$ and characterized as a priority pollutant by the United States Environmental Protection Agency (USEPA). ${ }^{32}$

The assimilation and, consequently, contamination of $\mathrm{Tl}$ are mainly attributed to the similarity between the $\mathrm{Tl}^{+}$and $\mathrm{K}^{+}$ions, results in metabolic processes disorders associated with potassium $(\mathrm{K})$ in the body. ${ }^{33}$ Human $\mathrm{Tl}$ intoxication may occur through inhalation, dermal absorption and ingestion of contaminated food and/or water. If present in the bloodstream, $\mathrm{Tl}$ is transported throughout the body, 
accumulating in the bones, kidneys and central nervous system. $^{8}$

It is estimated that in 2018, the global production of Tl was close to $8,000 \mathrm{~kg} \cdot{ }^{34}$ According to Liu et al. ${ }^{7}$ the majority of $\mathrm{Tl}$ deposits are concentrated in the Northern hemisphere (Europe, Asia, and North America), with some deposits existing in the Southern hemisphere (South America and Oceania). The countries with the most Tl deposits are Macedonia, Switzerland, the United States, France, and China. ${ }^{18,35-37}$ In 2005, new deposits with substantial levels of Tl have been identified in Brazil, China, Macedonia, and Russia. ${ }^{34}$

The geological environment of $\mathrm{Tl}$ minerals is different in many parts of the world, but most $\mathrm{Tl}$ is found in sulfide deposits of $\mathrm{Pb}, \mathrm{Zn}, \mathrm{Fe}, \mathrm{Cu}, \mathrm{As}, \mathrm{Au}, \mathrm{Ag}, \mathrm{Hg}, \mathrm{Sb}$, Se, or $\mathrm{Sn} .{ }^{38-42} \mathrm{Tl}$ ores, independent of other metals in composition, are very rare. So far, around 50 have been discovered in nature. They include sulfosalt minerals, sulfide minerals, selenide minerals, sulfate minerals, sulfur chloride mineral, and oxide mineral. ${ }^{7,8}$

The State of Bahia(BA), Brazil, stands out geochemically for presenting important manganese districts, such as Serra da Jacobina, Urandi-Licínio de Almeida, in Southern Bahia, and the most expressive in western Bahia. In the municipality of Barreiras-BA, in the western region of Bahia state, the first known worldwide occurrence of manganese-cobalt-thallium association was discovered in a continental geological environment. However, in a list of more than 50 registered occurrences of manganese ore in the western region-BA, geological, geochemical and environmental impact studies are still incipient, as in the case of Perdizes Mine. ${ }^{43}$

The Perdizes Mine is located in the municipality of São Desidério, approximately $50 \mathrm{~km}$ from the city of Barreiras. In the 1980 s and 90 s, it was the main mining enterprise in western of Bahia, intended for the production of Mn ore for the national steel industry. ${ }^{43}$

Various reviews articles ${ }^{12,18,44,45}$ associating $\mathrm{Tl}$ with public health and environmental contamination can be found in the specialized literature. A compilation of incidents involving the contamination of rivers by $\mathrm{Tl}$ in provinces of China between 2010 and 2018, and recent technologies for $\mathrm{Tl}$ removal from wastewater was presented in the literature. ${ }^{7}$

In the present study, the occurrence of $\mathrm{Tl}$ was evaluated in soil samples and ore tailings, from an area where a deactivated manganese mine is located, called Perdizes Mine, western Bahia Region, Brazil, and also in water and sediment samples river, located approximately $700 \mathrm{~m}$ from the mine area.

\section{Experimental}

\section{Characterization of the study area}

The study area comprises a deactivated Mn mine (called Perdizes Mine), located in the municipality of São Desidério, in the western region of Bahia, Brazil (Figure 1).

The study area is located on the hydrographic limits of the Fêmeas River basin which flows into Rio Grande, the latter being one of the main tributaries of the left bank of the São Francisco River. For the historical series from 1977 to 2007, the Fêmeas River basin annual precipitation average was $1121.83 \mathrm{~mm}$ year ${ }^{-1}$, with a maximum of $1585.40 \mathrm{~mm}$ and the minimum of $662.83 \mathrm{~mm}$, with an annual flow average of $52.17 \mathrm{~m}^{3} \mathrm{~s}^{-1} .46$

The predominant pedogenic material in the study area is the dystrophic red yellow latosol with sandy texture, with low values of ion exchange capacity (IEC) and high acidity due to low base saturation and high aluminum saturation. ${ }^{47}$ This property is the result of the high degree of weathering of the soil that favored the pedogenetic latolization process that basically consists of the removal of silica and basic cations (i.e., $\mathrm{Ca}^{2+}, \mathrm{Mg}^{2+}$, and $\mathrm{K}^{+}$) of the soil profile, with consequent relative enrichment of iron and aluminum oxides. ${ }^{48}$

The region where the Perdizes Mine is located comprises areas of intense agricultural activity of soybean, corn, and cotton crops. The municipality of São DesidérioBA has the largest cultivated land area in the country, with 600,000 ha of plantation, and stands out for the large production of soybeans and cotton, being one of the largest producers in Brazil. ${ }^{49}$

From the environmental approach, the study area is currently an environmental liability, with several deactivated ditches and unreformed from a geotechnical perspective, in addition to the presence of bulky piles of tailings and inert materials, placed next to the central pit. These piles are located at a distance of approximately $700 \mathrm{~m}$ from the right bank of the Fêmeas River, with risks of transporting this material to the river. During the period of this study, the Perdizes Mine was deactivated, and the area had not been rehabilitated.

\section{Sample collection and preparation procedure}

Samples of soils and ore tailings were collected in the central pit and the vicinity of the mine. The sediments and water were collected in Fêmeas River, following the National Guide for the Collection and Preservation of Samples of the National Water Agency. ${ }^{50}$ In Figure 2, it is possible to observe the study area as well as the indication of the collection points. 

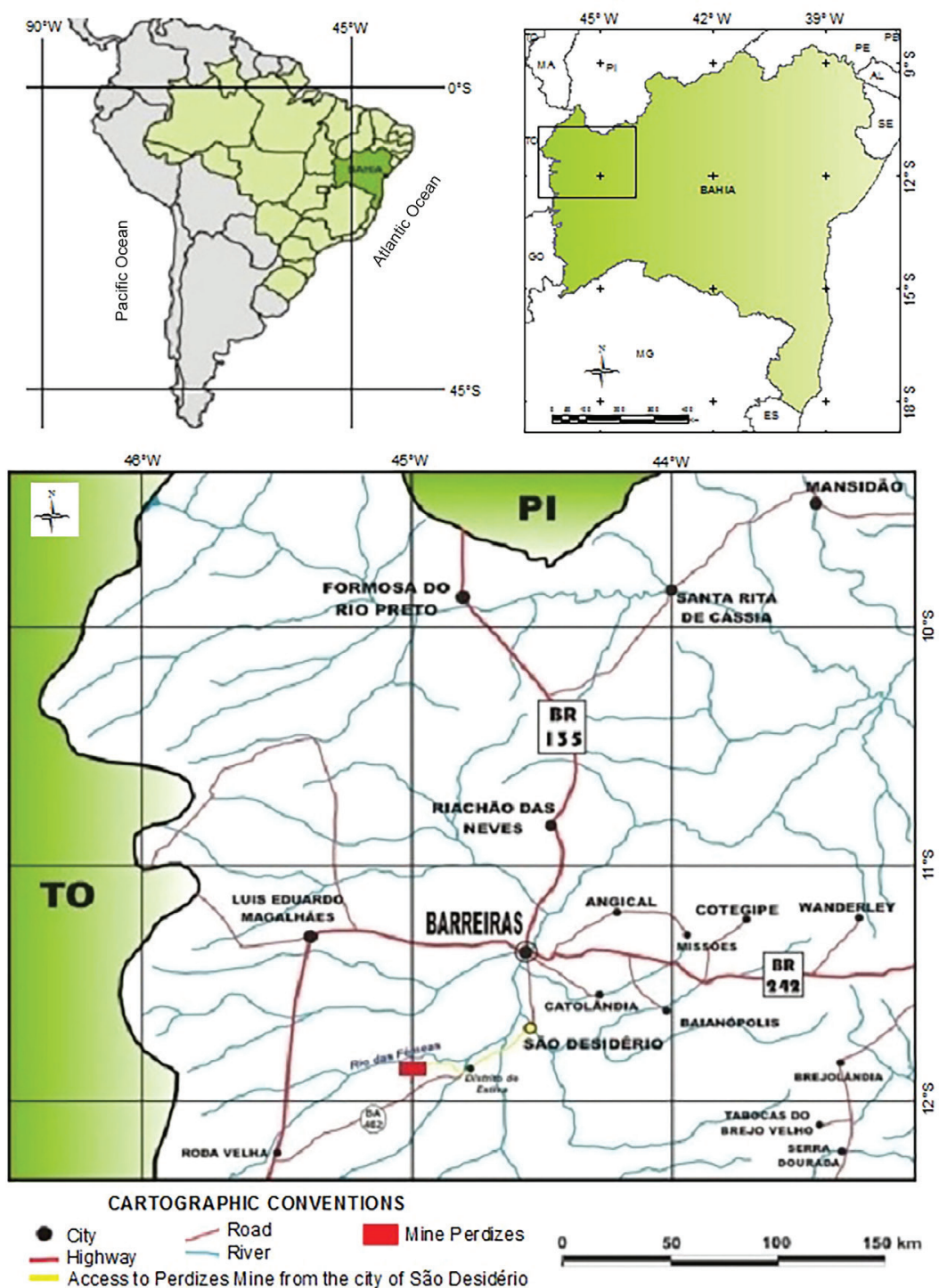

Figure 1. Map with the location of the study area in the municipality of São Desidério, western Bahia.

\section{Soils and sediments}

Soil samples were collected at a depth of $0-20 \mathrm{~cm}$ that corresponds to the root zone, at sampling points (MP and PP), equidistant (ca. $500 \mathrm{~m})$ from the ore tailings piles. The points called MPn ( $\mathrm{n}=1$ to 7$)$ are located within the main mining pit area MP1 $=12^{\circ} 27^{\prime} 42.14^{\prime \prime} \mathrm{S}$, $45^{\circ} 19^{\prime} 23.65^{\prime \prime} \mathrm{W} ; \quad \mathrm{MP} 2=12^{\circ} 27,39.80 \% \mathrm{~S}$, $45^{\circ} 19^{\prime} 24.70 " \mathrm{~W} ; \mathrm{MP} 3=12^{\circ} 27 \cdot 37.10 " \mathrm{~S}$, $45^{\circ} 19$ '23.30"W; MP4 = 12॰27'36.90" S,

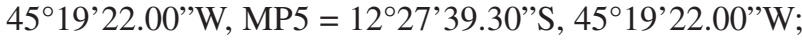
MP6 $=12^{\circ} 27^{\prime} 41.00^{\prime \prime} \mathrm{S}, 45^{\circ} 19^{\prime} 23.00^{\prime \prime} \mathrm{W}$ and, MP7 = $12^{\circ} 27^{\prime} 41.10^{\prime \prime} \mathrm{S} ; 45^{\circ} 19^{\prime} 22.00^{\prime \prime} \mathrm{W}$, that characterize samples from the bottom of the main pit (MP5, MP6, and MP7), the slopes of the pit (MP3 and MP4) and, the edges of the pit (MP1 and MP2), an area with no apparent soil movement.
As there are indications of the use of mining waste in paving roads, samples were collected at point PP1 $\left(12^{\circ} 27^{\prime} 6.22^{\prime \prime} \mathrm{S}, 45^{\circ} 19^{\prime} 15.90^{\prime \prime} \mathrm{W}\right)$, a stretch of road that leads to the village Perdizes, and at point PP3 $\left(12^{\circ} 27^{\prime} 39.51^{\prime \prime} \mathrm{S}, 45^{\circ} 19^{\prime} 20.51^{\prime \prime} \mathrm{W}\right)$, the section of the road that is next to the mining pit. The collections of these samples were carried out at $0.5 \mathrm{~m}$ from the margins of the runway.

Sampling was also carried out at point PP2 $\left(12^{\circ} 27^{\prime} 21.34^{\prime \prime} \mathrm{S}, 45^{\circ} 19^{\prime} 8.36^{\prime \prime} \mathrm{W}\right)$, approximately $1.0 \mathrm{~km}$ from the mine, a place that reflects the natural landscape of the region (cerrado), without soil movement and/or mining activities.

The sediment samples were collected in the bed of the Fêmeas River, in the stretch that passes through the village of Perdizes. With the aid of a Petersen dredge, sediment samples were collected in the shallower regions (CR1) 


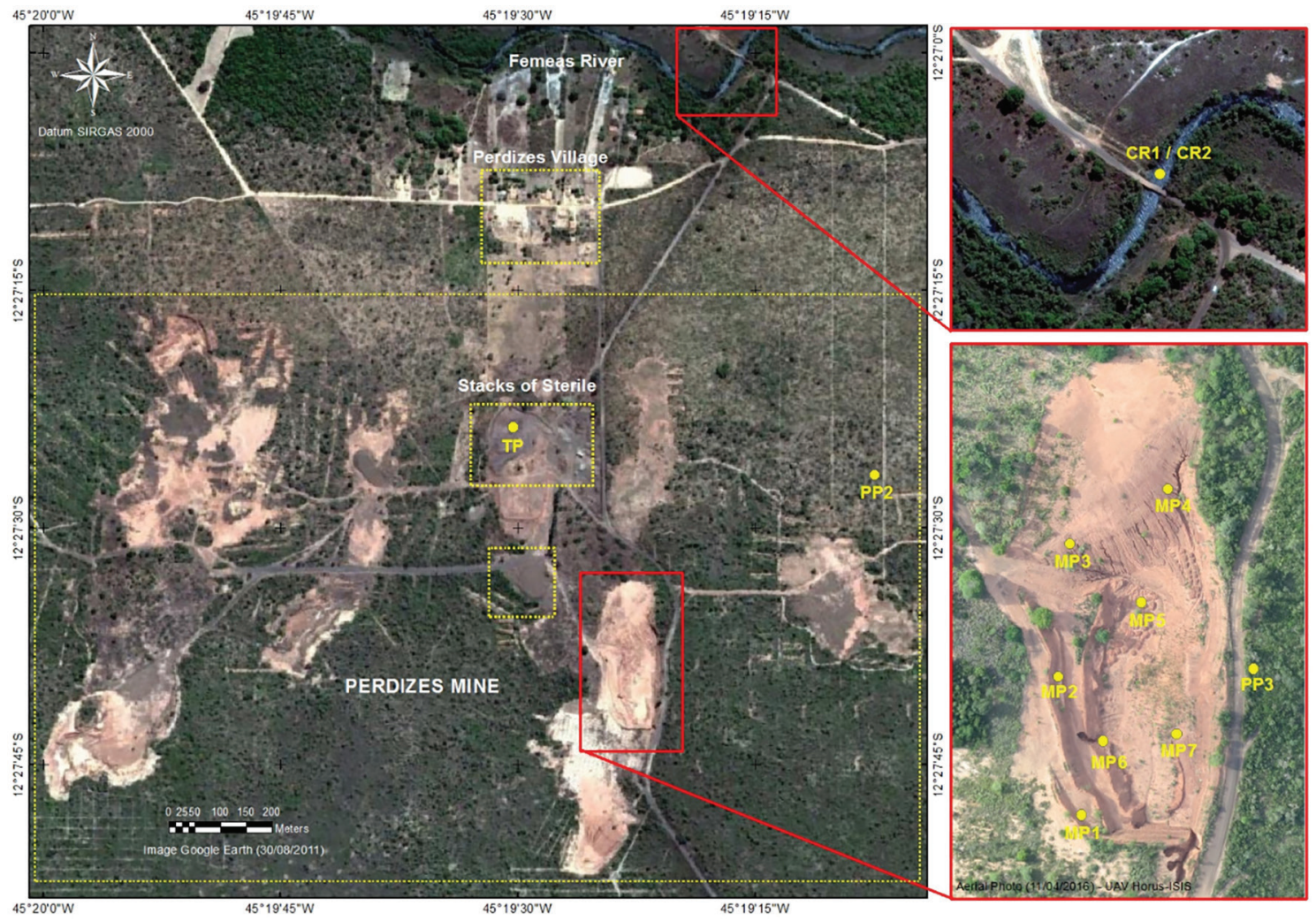

Figure 2. Google Earth image of the Perdizes Mine area with indications of sample collection points.

and the center of the river channel (CR2), at a sampling point (point CR) located at $12^{\circ} 26^{\prime} 59.96$ " south latitude and $45^{\circ} 19^{\prime} 15.92^{\prime \prime}$ west longitude.

With the care of discarding the portion of the collected material that had contact with the metallic part of the equipment used in the sampling, the sediment and soil samples were packed in plastic bags, labeled and transported to the laboratory. In the laboratory, the samples were placed in plastic trays for separation and removal of pieces of wood, leaves, and so on. Then, the samples were dried in greenhouses at $105^{\circ} \mathrm{C}$ for $24 \mathrm{~h}$, crushed in an agate mortar, sieved, reserving the fraction with a particle size less than 200 mesh for further analysis.

A composite sample of ore fragments (TP) was performed on the ore tailings pile (TP1 12 $27^{\circ} 25.67$ 'S, $45^{\circ} 19^{\prime} 27.11^{\prime \prime}$ ) located near the central pit. The samples were mechanically ground, sieved (classified) in a 200 mesh, and mixed to constitute a representative sample of the tailing pile.

Water

Water samples (WS1 and WS2) were collected in Fêmeas River, geographical coordinates $12^{\circ} 26^{\prime} 59.96^{\prime \prime} \mathrm{S}$ and $45^{\circ} 19^{\prime} 15.92^{\prime \prime} \mathrm{W}$, located $700 \mathrm{~m}$ from the mine. The water samples were collected in polyethylene bottles previously washed with $10 \%\left(\mathrm{v} \mathrm{v}^{-1}\right)$ solution of $\mathrm{HNO}_{3}$ P.A. (Merck, Darmstadt, Germany) and ultrapure water, being transported to the laboratory under refrigeration $\left(4{ }^{\circ} \mathrm{C}\right)$.

Digestion of soil, sediment, and ore samples

The preparation of the samples (soils, sediments and ore) for the determination of $\mathrm{Tl}, \mathrm{Fe}$, and $\mathrm{Mn}$ was carried out by sample partial digestion, using the extraction method with aqua regia and addition of hydrogen peroxide for organic matter degradation.

Following the procedure described by Jakubowska et al., ${ }^{51}$ a mass of $1.0 \mathrm{~g}$ of sieved sample (200 mesh) was reserved in a round-bottomed flask equipped with a reflux condenser. Subsequently, a $40 \mathrm{~mL}$ aliquot of aqua regia (prepared in a $3: 1$ ratio $\left(\mathrm{v} \mathrm{v}^{-1}\right)$ of $37 \%$ hydrochloric acid $\left(\mathrm{v} \mathrm{v}^{-1}\right)$ and $65 \%$ nitric acid $\left(\mathrm{v} \mathrm{v}^{-1}\right)$ was added to the flask and the mixture was left to stand for $48 \mathrm{~h}$.

After standing, the mixture was heated to reflux for $2 \mathrm{~h}$ at $70{ }^{\circ} \mathrm{C}$, filtered and washed with $2.0 \mathrm{~mol} \mathrm{~L}^{-1}$ nitric acid solution. The filtrate was reserved in a Becker and evaporated in a heating plate at $70^{\circ} \mathrm{C}$. In order to mineralize all organic matter, in the final phase of evaporation, five portions of $0.5 \mathrm{~mL}$ of $30 \%$ hydrogen peroxide $\left(\mathrm{v} \mathrm{v}^{-1}\right)$ were added. To obtain the extract, the residue contained in the Becker was dissolved in $1.0 \mathrm{~mL}$ of $37 \%$ hydrochloric 
acid $\left(\mathrm{v} \mathrm{v}^{-1}\right)$. Then, the solution was added with $2.5 \mathrm{~mL}$ of $1.0 \mathrm{~mol} \mathrm{~L}^{-1}$ ascorbic acid and $6.25 \mathrm{~mL}$ of $0.2 \mathrm{~mol} \mathrm{~L}^{-1}$ ethylenediaminetetraacetic acid (EDTA) solution. The $\mathrm{pH}$ was adjusted to 4.5 with ammonia and the solution was transferred quantitatively to a $25 \mathrm{~mL}$ volumetric flask and swollen with ultrapure water (Milli-Q ${ }^{\circledR}$, Darmstadt, Germany). The same procedure was performed for the blank sample preparation (extract without sample).

In assessing the efficiency of the Tl extraction method, the sample preparation procedure was also applied to samples of IRMM BCR ${ }^{\circledR}-320$ certified river sediment reference material (Institute for Reference Materials and Measurements, Geel, Belgium).

\section{Chemical analysis}

\section{Determination of $\mathrm{TI}, \mathrm{Mn}$, and Fe contents}

The Tl levels in soil, sediment, ore and river water samples were determined by differential pulse anodic stripping voltammetry (DPASV). DPASV measurements used portable potentiostat/galvanostat (Dropsens' $\mu$ Start 400). In the electrochemical cell, a conventional arrangement of three electrodes was used, the working electrode being the palladium film deposited in silver amalgam (PdF-AgSAE), the auxiliary stainless-steel electrode and the $\mathrm{Ag} / \mathrm{AgCl}$ reference electrode $\left(3.0 \mathrm{~mol} \mathrm{~L}^{-1}\right.$ $\mathrm{KCl})$. The voltammetric parameters used, as well as the steps involved are described in detail by Santos et al..$^{52}$

The levels of Mn and Fe in the soil, sediment and ore samples were determined by flame atomic absorption spectroscopy (FAAS) and the measurements used a Varian model AA 240FS atomic absorption spectrometer with background correction using a deuterium lamp.

\section{Determination of the content of organic matter (OM) in soil and sediment samples}

The OM in the soil and sediment samples was determined by the gravimetric method of mass loss by ignition. ${ }^{53,54}$ In this procedure, a sample of approximately $4 \mathrm{~g}$, previously dried at $105^{\circ} \mathrm{C}$, was heated to $250{ }^{\circ} \mathrm{C}$ for $5 \mathrm{~h}$ in a muffle oven. The OM content was estimated by the difference between the initial and final mass of the sample.

\section{$\mathrm{X}$-ray diffraction analysis of the ore}

The X-ray diffraction (XRD) analysis on the ore sample was performed using a Rigaku X-ray diffractometer model Ultima IV with $\mathrm{Cu} \mathrm{K} \alpha$ radiation source $(\lambda=1.5406 \AA)$ generated at $40 \mathrm{kV}$ and $30 \mathrm{~mA}$. The XRD measurements were performed at scanning angles $(2 \theta)$ between 10 to $90^{\circ}$, in $0.02^{\circ}$ steps and counting time of 2 s per step. The crystalline phases of the ore samples were identified from the X-ray diffractograms, comparing them with diffraction patterns from the International Center for Diffraction Data (ICDD)/Joint Committee of Powder Diffraction Standards (JCPDS) database.

\section{Results and Discussion}

\section{Regional geological context}

The western region of the State of Bahia is inserted in the northern domain of the São Francisco Craton (CSF), considered one of the largest geological entities of the South American Platform. In the study area, region of the municipality of São Desidério (Figure 3), lithostratigraphic units of sedimentary origin with neoproterozoic age, represented by the Bambuí Group, occur. The Bambuí Group, in turn, is covered by the Cretaceous continental wind sedimentation that corresponds to the Urucuia Group (Sanfranciscana Basin). Finally, topping this whole package described above, there are superficial cenozoic coverings. ${ }^{55}$

The Mn occurrence in the Perdizes Mine and its surrounding is associated with genetic processes of supergenic/lateritic origin, and consequently present a diversity of types and forms that define the mineralizing controls of this mineral deposit. ${ }^{43}$ Among the mineralizing processes, Bonfim et al. ${ }^{43}$ describes the manganese mineralizations in the Vau da Boa Esperança region, near Perdizes Mine, considering that the primary concentration of this deposit was in a marine platform environment, under oxidizing and reducing conditions. During the deformational events, there was an imminent performance of hydrothermal processes and, subsequently, the action of supergenic processes predominated, due to the solubility of manganese and oscillations in the water table, concentrating the ore in the lateritic profile, completing the metallogenic profile of this deposit.

At Perdizes Mine (Figure 4), the Mn mineralization manifests itself in the form of purplish silty sandstones (protominium), lateritized concretions (pisolites) of red orange color due to the oxidized iron, decimetric redyellowish laterites in some points adjacent to the mine, oxisol lightly stained with Mn oxide and blue dense Mn ore without visible quartz (Figure 4b), considered as the predominant type. All of these typologies, in the form of continuous or isolated occurrences, in the various pits that make up the mine, mainly in the "Cava Cotton", and also through blocks rolled at the base of the pits, revealing the mineralization genetically defined by pedogenic/supergenic processes.

In the X-ray diffraction analysis of dense bluish Mn ore without visible quartz, it was only possible to confirm the presence of pyrolusite, as the main oxidized phase in the 
composition of the ore (Figure 4c). Probably, the quartz present, in its recrystallization phases, may have obliterated the identification of other Mn oxides such as todorokite, cryptomelane and vernadite that also make up the Mn ore of Perdizes Mine. ${ }^{57,58}$
Bluish gray Mn ore is the typology that stands out the most due to its predominance in the study area, composing a non-continuous concrete horizon based on alluvial coverings resulting from the Urucuia Group. This ore is also concentrated in the middle of the tailings piles, in
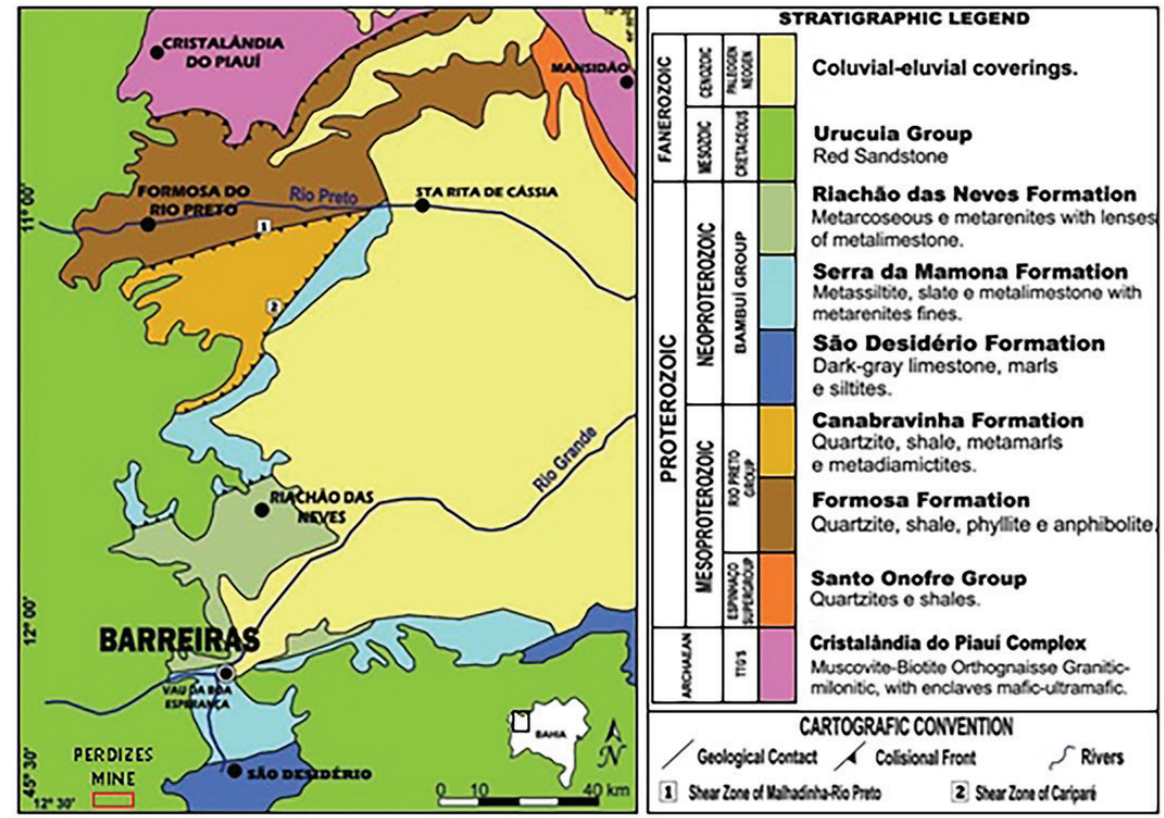

Figure 3. Geological map of the eastern edge of the Sanfranciscana Basin with the sedimentary covers and windows of the basement of the São Francisco Craton in western Bahia (adapted from Bizzi et al. ${ }^{56}$ ).

(a)
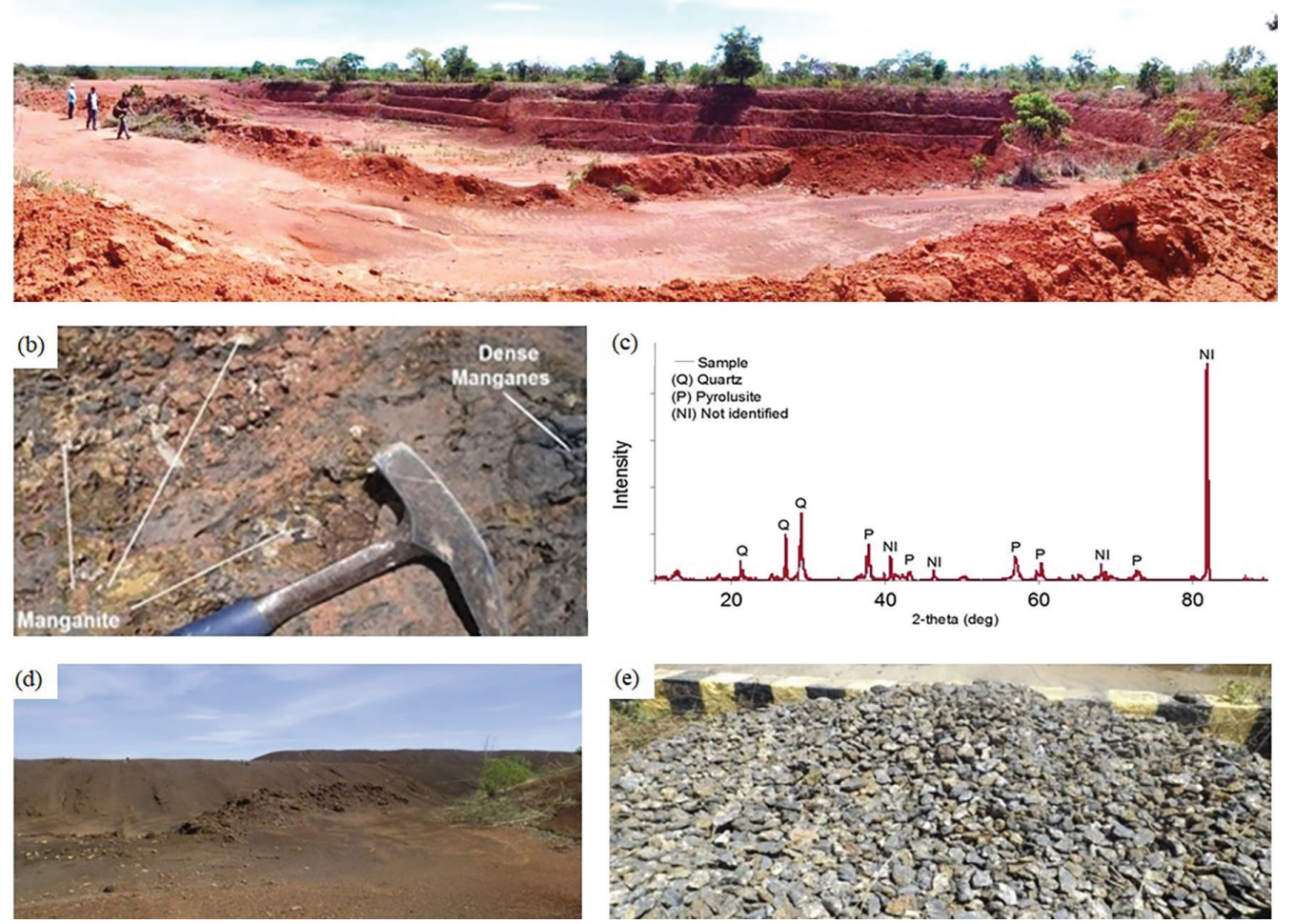

Figure 4. (a) Panoramic photograph of the Main Cava (Cotton); (b) bluish dense manganese ore without visible quartz; (c) diffractogram referring to the bluish dense gray manganese ore sample; (d) bluish gray and dense manganese ore dispersed in the tailings piles; (e) manganese ore separated for processing. 
the mine pit and also gathered in groups for processing (Figures $4 \mathrm{~d}$ and $4 \mathrm{e}$ ).

Further details on the procedural and genetic relationships of Mn mineralization, as well as a more detailed understanding of the types, shapes and compositions of the ore, can be consulted in the work of Bonfim et al..$^{43}$

Concentration of $\mathrm{Tl}, \mathrm{Mg}, \mathrm{Fe}$, and $\mathrm{OM}$ in soil, sediment, ore and water samples from Perdizes Mine area and its surroundings

In the determination of $\mathrm{Tl}$ by DPASV, we obtained calibration curves in two working ranges: from 0.03 to $0.15 \mathrm{mg} \mathrm{L}^{-1}$ (correlation coefficient, $\mathrm{R}=0.9982$ ) and 0.2 to $4.0 \mathrm{mg} \mathrm{L}^{-1}(\mathrm{R}=0.9944)$, with limit of detection (LOD) of $0.01 \mathrm{mg} \mathrm{L}^{-1}$. The studies of addition and recovery of $\mathrm{Tl}$ in extracts of samples (soil, sediments, and ores) digested with aqua regia and free of $\mathrm{Tl}$, showed recovery values between 88.2 to $108.5 \%$. The precision of the method was assessed by successive measurements $(n=6)$ in aqua regia solutions containing $\mathrm{Tl}$ at concentrations of 0.08 , 0.60 and $4.00 \mathrm{mg} \mathrm{L}^{-1}$. Under these conditions, the variation coefficients (RSD) obtained for $\mathrm{Tl}$ were less than 3.0\%.

In the case of determination of Fe and Mn levels by FAAS, the LODs were 0.03 and $0.01 \mathrm{mg} \mathrm{L}^{-1}$, respectively. The calibration curves for both metals were in the range of 0.2 to $2 \mathrm{mg} \mathrm{L}^{-1}(\mathrm{R}=0.9996$ for $\mathrm{Fe}$ and $\mathrm{R}=0.9983$ for $\mathrm{Mn})$ and precision in the range of 1 to $3 \%$.

In the evaluation of the efficiency of the extraction method for $\mathrm{Tl}$, performed with the certified reference material (BCR ${ }^{\circledR}-320$, from the Community Bureau of Reference, containing $0.5 \mathrm{mg} \mathrm{kg}^{-1}$ for $\mathrm{Tl}$ ), values of $0.44 \pm 0.05 \mathrm{mg} \mathrm{kg}^{-1}$ were obtained for $\mathrm{Tl}$, indicating recoveries of around $89 \%$, with the sample preparation protocol used.

Table 1 shows the levels of $\mathrm{Tl}, \mathrm{Mn}, \mathrm{Fe}$ and $\mathrm{OM}$ in ore samples from the tailings pile (TP), from soils in the mining area and central pit (MP1 to MP7), of soils in the area adjacent to the mine (PP1 to PP3), of water (WS1 and WS2) and sediment (CR1 and CR2) of the Fêmeas River which is located near Perdizes Mine.

The samples collected in the mining area and central pit (MPn, $\mathrm{n}=1,2,3,4,5,6$, and 7), showed Tl levels from 0.64 to $13.82 \mathrm{mg} \mathrm{kg}^{-1}$, and $\mathrm{Mn}$ from 0.02 to $0.39 \%\left(\mathrm{~m} \mathrm{~m}^{-1}\right)$. These values were lower than those observed at two points in the area adjacent to the mine (PP1 and PP3), as well as those observed in the tailings pile that presented the highest $\mathrm{Tl}\left(473 \mathrm{mg} \mathrm{kg}^{-1}\right)$ and $\mathrm{Mn}\left(34.21 \mathrm{mg} \mathrm{kg}^{-1}\right)$ concentrations (Table 1).

The PP3 and PP1 samples collected on the roadsides that give access to the mining area and the Perdizes village, showed significant concentrations of $\mathrm{Tl}\left(99\right.$ and $80 \mathrm{mg} \mathrm{kg}^{-1}$, respectively). It was observed evidences of the use of waste from mine, for road terracing (bluish coloration of the road, resulting from the mechanical incorporation of Mn ore tailings to the road soil). Probably, these levels are associated with the use of ore tailings from the tailing's piles, which presented concentrations in the order of $473 \mathrm{mg} \mathrm{kg}^{-1}$, for the practice of graveling these roads. This hypothesis may be confirmed by the $\mathrm{Tl}$ and Mn contents

Table 1. Average levels of Tl, Mn, Fe, and OM in the tailings samples of ore, soil, sediments, and water

\begin{tabular}{|c|c|c|c|c|c|}
\hline Sampling location & Sample identification & $\mathrm{Tl} /\left(\mathrm{mg} \mathrm{kg}^{-1}\right)$ & $\mathrm{Mn} / \%\left(\mathrm{~m} \mathrm{~m}^{-1}\right)$ & $\mathrm{Fe} / \%\left(\mathrm{~m} \mathrm{~m}^{-1}\right)$ & $\mathrm{OM} / \%\left(\mathrm{~m} \mathrm{~m}^{-1}\right)$ \\
\hline Tailings piles & $\mathrm{TP}$ & $473 \pm 18$ & 34.21 & 1.69 & 1.83 \\
\hline \multirow{7}{*}{ Mining area, central pit } & MP1 & $0.64 \pm 0.03$ & 0.02 & 3.34 & 0.90 \\
\hline & MP2 & $3.29 \pm 0.11$ & 0.20 & 3.08 & 1.09 \\
\hline & MP3 & $5.30 \pm 0.33$ & 0.26 & 3.96 & 0.96 \\
\hline & MP4 & $13.82 \pm 1.38$ & 0.39 & 5.33 & 1.25 \\
\hline & MP5 & $10.13 \pm 0.18$ & 0.37 & 4.92 & 1.37 \\
\hline & MP6 & $8.05 \pm 0.39$ & 0.04 & 3.03 & 0.67 \\
\hline & MP7 & $1.51 \pm 0.13$ & 0.08 & 2.85 & 0.56 \\
\hline \multirow{3}{*}{ Adjacency to mine } & PP1 & $80.14 \pm 0.66$ & 10.18 & 4.69 & 1.65 \\
\hline & PP2 & $<\mathrm{LOD}$ & 0.03 & 3.35 & 0.70 \\
\hline & PP3 & $99.99 \pm 1.66$ & 9.68 & 3.59 & 1.30 \\
\hline \multirow{2}{*}{ River sediment } & CR1 & $31.14 \pm 1.23$ & 2.79 & 1.80 & 2.65 \\
\hline & $\mathrm{CR} 2$ & $3.40 \pm 0.50$ & 0.38 & 0.37 & 2.84 \\
\hline \multirow{2}{*}{ River water } & WS1 & $<\mathrm{LOD}$ & $0.10^{\mathrm{a}}$ & $0.40^{\mathrm{a}}$ & n.d. \\
\hline & WS2 & $<$ LOD & $0.12^{\mathrm{a}}$ & $0.43^{\mathrm{a}}$ & n.d. \\
\hline
\end{tabular}

an mg L-1. LOD: limit of detection; n.d.: not determined; OM: organic matter. 
observed in the sample PP2 (< LOD and $0.03 \mathrm{mg} \mathrm{kg}^{-1}$, respectively), a point without signs of the presence of mining waste mixed with the soil.

The literature available ${ }^{12,59-61}$ reports mean basal $\mathrm{Tl}$ levels from 0.20 to $1.5 \mathrm{mg} \mathrm{kg}^{-1}$ in soil from areas without contamination by mining activities. However, contaminated soils close to mining areas showed levels such as: 16.4 to $35.4 \mathrm{mg} \mathrm{kg}^{-1}$, Lanmuchang province of Guizhou/China; ${ }^{62}$ 2.43 to $5.19 \mathrm{mg} \mathrm{kg}^{-1}$, Yunfu city, Guangdong Province/ China; ${ }^{63}$ up to $7.0 \mathrm{mg} \mathrm{kg}^{-1}$, Rosh Pinah, Namibia; ${ }^{20} 100$ to $1000 \mathrm{mg} \mathrm{kg}^{-1}$, Swiss Jura mountains, Switzerland; ${ }^{64}$ 0.87 to $2.65 \mathrm{mg} \mathrm{kg}^{-1}$, Madrid, Spain; ${ }^{65}>50 \mathrm{mg} \mathrm{kg}^{-1}$, Silesia-Krakow, Poland; ${ }^{66}$ and a mean of $600 \mathrm{mg} \mathrm{kg}^{-1}$, Allchar, Macedonia. ${ }^{67}$

The $\mathrm{Tl}$ average content observed in the central pit of the mine, (MPn, $\mathrm{n}=1,2,3,4,5,6$ and 7) in the mining area was $6.10 \mathrm{mg} \mathrm{kg}^{-1}$. These levels are between 4 and 30 times higher than those observed in uncontaminated soils in the European continent ${ }^{60}$ and the Chinese continent. ${ }^{68}$

Karbowska ${ }^{8}$ point out that significant concentrations of $\mathrm{Tl}$ in surface soils represents a great threat due to the possible absorption by the plant roots, which store $\mathrm{Tl}$ in its biomass. In this context, Tl may enter the food chain and accumulate in living organisms, which can lead to health problems. Vaněk et al. ${ }^{41,66,69-73}$ carried out several studies on the dynamics of $\mathrm{Tl}$ in the soil, its mineral phases, and the factors that control its absorption by plants.

The sediment samples from Fêmeas River presented T1 levels of 31.14 and $3.40 \mathrm{mg} \mathrm{kg}^{-1}$, for sample CR1 (collected on the river bank) and CR2 (collected in the middle of the river channel), respectively, suggesting that the particles leaching from the ore to the receiving aquatic body. The observed levels of $\mathrm{Tl}$ and $\mathrm{Mn}$ on sample CR2, were, on average, nine times lower than those obtained for the sample CR1. Possibly, this occurs due the effect of the greater dispersion of the sediment in the middle of the river channel where the water flow is greater.

Although the $\mathrm{Tl}$ associated with the river sediments may be released in the water column, its capacity to transfer to the water body will depend on environmental factors, such as variations in $\mathrm{pH}$ in the river water, redox potential of the environment and presence of organic matter. In the analysis of water samples (WS1 and WS2) from the Fêmeas River, the $\mathrm{Tl}$ concentration was below the limit of detection of the analytical method used (DPASV) (LOD estimated at $\left.0.89 \mu \mathrm{g} \mathrm{L}^{-1}\right)$. Limits considered environmentally safe for $\mathrm{Tl}$ in water are in the order of $2.0 \mu \mathrm{g} \mathrm{L}^{-1} .^{74}$

The fact that $\mathrm{Tl}$ was not detected in the water samples of the Fêmeas River, may be an indication that the $\mathrm{Tl}$ extractable with the aqua regia is not in the exchangeable or leachable fraction of the soil, but probably in the reducible fraction. According to Yang et al. ${ }^{75}$ in acidic soils with a low OM content, as in the case of the red yellow latosol in the study area, most of $\mathrm{Tl}$ (ca. 80\%) of anthropogenic origin is incorporated in the more labile fractions of the soil, mainly retained in the reducible fraction than in the surface adsorption sites (exchangeable fraction). The $\mathrm{Tl}$ content in the reducible fraction, makes strong bonds with the oxides and hydroxide of $\mathrm{Mn}$ and $\mathrm{Fe}$ and in the exchangeable fraction, the hydroxyls and other radicals of the soil surface are more easily saturated by $\mathrm{H}^{+}$and other cations (i.e., $\mathrm{Al}^{3+}$ and $\mathrm{Fe}^{3+}$ ). ${ }^{39,75,76}$

In the reducible fraction of the soil, $\mathrm{Tl}$ is associated preferentially with $\mathrm{Mn}$ than $\mathrm{Fe}$, due to the high affinity of $\mathrm{Tl}$ with Mn oxide. ${ }^{75,76} \mathrm{Jia}$ et al. ${ }^{77}$ studying $\mathrm{Tl}$ transport to plants in rhizospheric soils, found that most of the labile $\mathrm{Tl}$ was located in the reducible fraction and in this fraction there was a significantly positive correlation between $\mathrm{Tl}$ and $\mathrm{Mn}$, but the same correlation was not observed between $\mathrm{Tl}$ and $\mathrm{Fe}$.

In order to identify patterns in the distribution of the samples and to verify which variables are responsible for the similarities or differences between the samples of soils and sediments collected in the study area, the results for $\mathrm{Tl}, \mathrm{Mn}, \mathrm{Fe}$, and $\mathrm{OM}$ contents were submitted to principal component analysis (PCA).

According to the criterion of Kaiser ${ }^{78}$ for the choice of the main components (PC) that best explained the set of variables, the four variables under study $(\mathrm{Tl}, \mathrm{Mn}, \mathrm{Fe}$, and OM contents) could be summarized in two PCs which together explained $88.4 \%$ of the variance of the original data set.

In the analysis of $\mathrm{PC} 1$ versus $\mathrm{PC} 2$, loading (Figure 5) and scores plots (Figure 6) were obtained. According to the loading plot (Figure 5) it was observed that variables

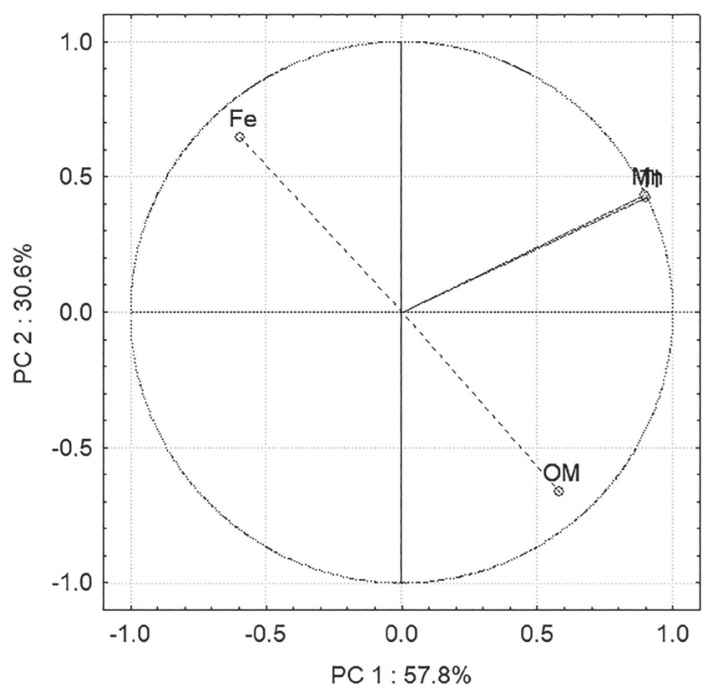

Figure 5. Loading plot of the variables for the components. 
$\mathrm{Tl}$ and Mn had a positive correlation, indicating that in soil and sediment samples the increase in the $\mathrm{Tl}$ content is accompanied by an increase in the Mn content. This correlation may be an indication of a common mineral source for these metals. This agrees with the fact that the soil and sediment samples are predominantly formed by pedogenic material from manganese ore.

The score plot (Figure 6) shows that there was a separation between four groups of samples: I, II, III, and IV. Regarding PC1, the groups formed by the samples PP3, PP1, and TP (II and III) presenting high levels of Tl and Mn and appear discriminated from the other samples group. The anomalous behavior, exhibited by samples PP3 and PP1 (II) in relation to other soil samples (I), corroborates with the observations pointed out in the text regarding mine tailings use for road terracing, indicating $\mathrm{Tl}$ contamination on the roads around the mine.

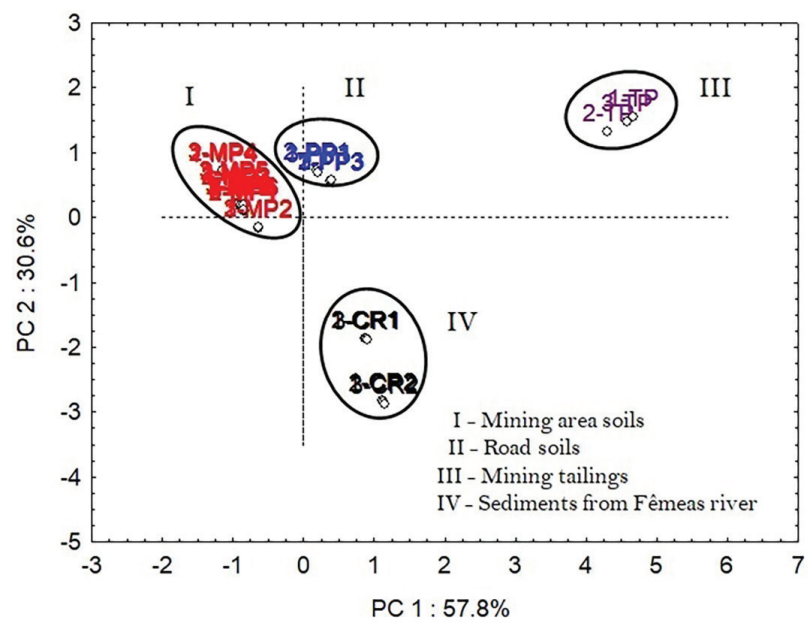

Figure 6. Score plot of PCA for variables Tl, Mn, Fe, and OM, in soil and sediment samples in the study area.

The group of sediment samples from Fêmeas River (CR1 and CR2) was separated from the groups of soil samples by PC2. This separation suggest that the sediment samples had the lowest levels of Fe and the highest levels of MO. Due to the higher levels of Tl and Mn in the CR1 sample, it could also be distinguished from the CR2 sample in the PCA.

Although it is not possible only from the levels of $\mathrm{Tl}$ extractable with aqua regia to infer about the Tl distribution in soil fractions, the correlation found between the $\mathrm{Tl}$ and Mn levels shows that, possibly, most of the Tl present in the soils and sediments samples in the study area is associated with the Mn oxide of the particles of the mining tailings and/or the reducible fraction of the soil.

In regions that $\mathrm{Tl}$ naturally occurring it is extremely important to know the base level values of this metal. Xiao et al. ${ }^{9}$ determined the Tl concentration in a Tl naturally occurring area in several compartments (rocks, water, soil, and sediment); they concluded that possible $\mathrm{Tl}$ dispersion patterns resulted from activities as excavations, artisanal mining, agricultural activities, and use of rocks containing Tl minerals for road terracing practices, (activity observed in the area of the present study), aggravating the problem of $\mathrm{Tl}$ dispersion and increasing the risk for biosphere.

\section{Conclusions}

The natural occurrence of Tl was found in ore tailings, soils, and sediments samples from a surrounding area of a deactivated $\mathrm{Mn}$ mine, located in the western region of Bahia. The $\mathrm{Tl}$ levels ranged from 0.64 to $473 \mathrm{mg} \mathrm{kg}^{-1}$, triggering an alert since most of the samples analyzed presented $\mathrm{Tl}$ concentrations above $1.0 \mathrm{mg} \mathrm{kg}^{-1}$, recognized as the maximum limit recommended (for arable soils) by environmental agencies in North America and Europe.

The PCA suggest a strong correlation between $\mathrm{Tl}$ and Mn levels, indicating that $\mathrm{Tl}$ is bound to the Mn oxide of the $\mathrm{Mn}$ ore particles and the reducible fraction of the soil and sediments. These preliminary results indicate that the exploitation of Mn ore in the western region of Bahia may have made $\mathrm{Tl}$ available in several environmental compartments.

Special attention should be directed for $\mathrm{Tl}$ dispersion around the mine, due to the use of ore tailings as gravel for road, evidenced by the levels of $\mathrm{Tl}$ found on the roadsides (80 and $99 \mathrm{mg} \mathrm{kg}^{-1}$ ) and in the river sediment (3.40 and $31.14 \mathrm{mg} \mathrm{kg}^{-1}$ ), located approximately $700 \mathrm{~m}$ from the central pit.

The preliminary results obtained in this study indicated the need for attention, monitoring and further scientific investigations of this geoenvironment, capable of dispersing natural Tl, its influence and risk to environmental health.

\section{Acknowledgments}

The authors are grateful to Fundação de Amparo à Pesquisa do Estado da Bahia (PRONEX ÁGUA and PPP 049/2011), INCT de Energia e Ambiente (INCT E\&A), Conselho Nacional de Desenvolvimento Científico e Tecnológico (CNPq) and Coordenação de Aperfeiçoamento de Pessoal de Nível Superior (CAPES) for providing grants, fellowships and financial support.

\section{Author Contributions}

Jorge Luís O. Santos and Giuliana M. G. Bueno were responsible for the data curation, formal analysis, investigation, methodology, and software analysis; Eder L. 
M. Flores for the investigation and methodology; Clayton R. Janoni and Luis G. Carvalho for the data curation and methodology; Ana Maria P. dos Santos and Oldair D. Leite conceptualization, data curation, formal analysis, funding acquisition, investigation, project administration, resources, supervision, writing original draft, review, and editing.

\section{References}

1. Callender, E.; Treatise Geochem. 2003, 9, 612.

2. Pavoni, E.; Covelli, S.; Adami, G.; Baracchini, E.; Cattelan, R.; Crosera, M.; Higueras, P.; Lenaz, D.; Petranich, E.; J. Geochem. Explor. 2018, 188, 1.

3. Lian, M.; Wang, J.; Sun, L.; Xu, Z.; Tang, J.; Yan, J.; Zeng, X.; Ecotoxicol. Environ. Saf. 2019, 169, 442.

4. Nordberg, G. F.; Fowler, B. A.; Nordberg, M.; Handbook on the Toxicology of Metals, $4^{\text {th }}$ ed.; Academic Press: London, UK, 2014.

5. Sawut, R.; Kasim, N.; Maihemuti, B.; Hu, L.; Abliz, A.; Abdujappar, A.; Kurban, M.; Sci. Total Environ. 2018, 642, 864.

6. Liu, J.; Wang, J.; Chen, Y.; Shen, C. C.; Jiang, X.; Xie, X.; Chen, D.; Lippold, H.; Wang, C.; Environ. Pollut. 2016, 213, 878.

7. Liu, J.; Luo, X.; Sun, Y.; Tsang, D. C. W.; Qi, J.; Zhang, W.; Li, N.; Yin, M.; Wang, J.; Lippold, H.; Chen, Y.; Sheng, G.; Environ. Int. 2019, 126, 771.

8. Karbowska, B.; Environ. Monit. Assess. 2016, 188, 640.

9. Xiao, T.; Guha, J.; Boyle, D.; Liu, C.-Q.; Zheng, B.; Wilson, G. C.; Rouleau, A.; Chen, J.; Environ. Int. 2004, 30, 501.

10. Nannoni, F.; Protano, G.; Riccobono, F.; Geoderma 2011, 161, 63.

11. Lindsay, M. B. J.; Moncur, M. C.; Bain, J. G.; Jambor, J. L.; Ptacek, C. J.; Blowes, D. W.; Appl. Geochem. 2015, 57, 157.

12. Belzile, N.; Chen, Y.-W.; Appl. Geochem. 2017, 84, 218.

13. Stefanowicz, A. M.; Woch, M. W.; Kapusta, P.; Geoderma 2014, 235,1 .

14. Ramani, S.; Dragun, Z.; Kapetanović, D.; Kostov, V.; Jordanova, M.; Erk, M.; Hajrulai-Musliu, Z.; Arch. Environ. Contam. Toxicol. 2014, 66, 514.

15. Tatsi, K.; Turner, A.; Sci. Total Environ. 2014, 473, 139.

16. Dinelli, E.; Lombini, A.; Appl. Geochem. 1996, 11, 375.

17. Xiao, T.; Guha, J.; Boyle, D.; Liu, C. Q.; Chen, J.; Sci. Total Environ. 2004, 318, 223.

18. Xiao, T.; Yang, F.; Li, S.; Zheng, B.; Ning, Z.; Sci. Total Environ. 2012, 421, 51.

19. Shu, X.-H.; Zhang, Q.; Lu, G.-N.; Yi, X.-Y.; Dang, Z.; Int. Biodeterior. Biodegrad. 2018, 128, 122.

20. Grösslová, Z.; Vaněk, A.; Oborná, V.; Mihaljevič, M.; Ettler, V.; Trubač, J.; Drahota, P.; Penížek, V.; Pavlů, L.; Sracek, O.; Kř́́bek, B.; Voegelin, A.; Göttlicher, J.; Drábek, O.; Tejnecký, V.; Houška, J.; Mapani, B.; Zádorová, T.; Environ. Pollut. 2018, $239,272$.
21. Vaněk, A.; Grösslová, Z.; Mihaljevič, M.; Ettler, V.; Trubač, J.; Chrastný, V.; Penížek, V.; Teper, L.; Cabala, J.; Voegelin, A.; Zádorová, T.; Oborná, V.; Drábek, O.; Holubík, O.; Houška, J.; Pavlů, L.; Ash, C.; J. Hazard. Mater. 2018, 343, 78.

22. Rodríguez, L.; Ruiz, E.; Alonso-Azcárate, J.; Rincón, J.; J. Environ. Manage. 2009, 90, 1106.

23. Ospina-Alvarez, N.; Głaz, Ł.; Dmowski, K.; KrasnodębskaOstręga, B.; Environ. Chem. Lett. 2014, 12, 435.

24. Resongles, E.; Casiot, C.; Freydier, R.; Dezileau, L.; Viers, J.; Elbaz-Poulichet, F.; Sci. Total Environ. 2014, 481, 509.

25. Lin, T.-S.; Nriagu, J.; J. Air Waste Manage. Assoc. 1998, 48, 151.

26. Peter, A. L. J.; Viraraghavan, T.; Environ. Int. 2005, 31, 493.

27. Repetto, G.; del Peso, A.; Repetto, M. In Thallium in The Environment; Nriagu, J. O., ed.; Wiley: New York, USA, 1998.

28. Dmowski, K.; Rossa, M.; Kowalska, J.; Krasnodębska-Ostręga, B.; Environ. Monit. Assess. 2015, 187, 4141.

29. Osorio-Rico, L.; Santamaria, A.; Galván-Arzate, S., In Neurotoxicity of Metals; Aschner, M.; Costa, L. G., eds.; Springer: Cham, 2017, p. 345.

30. Puccini, M.; Guazzelli, L.; Tasca, A. L.; Mezzetta, A.; Pomelli, C. S.; Water, Air, Soil Pollut. 2018, 229, 2.

31. World Health Organization (WHO); Guidelines for DrinkingWater Quality, $3^{\text {rd }}$ ed.; World Health Organization: Geneva, 2008, available at https://www.who.int/water_sanitation_health/ dwq/fulltext.pdf, accessed in January 2021.

32. https://www.epa.gov/sites/production/files/2015-09/documents/ priority-pollutant-list-epa.pdf, accessed in January 2021.

33. Grösslová, Z.; Vaněk, A.; Mihaljevič, M.; Ettler, V.; Hojdová, M.; Zádorová, T.; Pavlů, L.; Penížek, V.; Vaněčková, B.; Komárek, M.; Chrastný, V.; Ash, C.; J. Geochem. Explor. 2015, 159, 208.

34. https://prd-wret.s3-us-west-2.amazonaws.com/assets/ palladium/production/atoms/files/mcs-2019-thall.pdf, accessed in January 2021.

35. Ikramuddin, M.; Besse, L.; Nordstrom, P. M.; Appl. Geochem. 1986, 1,493 .

36. Janković, S.; Int. Geol. Rev. 1989, 31, 262.

37. Fan, Y.; Zhou, T. F.; Gabriel, V.; Hu, Q. H.; Yuan, F.; Zhang, X.; Geol. Sci. Technol. Inf. 2005, 24, 55.

38. Zitko, V.; Sci. Total Environ. 1975, 4, 185.

39. Jakubowska, M.; Pasieczna, A.; Zembrzuski, W.; Świt, Z.; Lukaszewski, Z.; Chemosphere 2007, 66, 611.

40. Xiong, Y.; Environ. Chem. 2009, 6, 441.

41. Vaněk, A.; Komárek, M.; Chrastný, V.; Galušková, I.; Mihaljevič, M.; Šebek, O.; Drahota, P.; Tejnecký, V.; Vokurková, P.; J. Geochem. Explor. 2012, 112, 212.

42. Karbowska, B.; Zembrzuski, W.; Jakubowska, M.; Wojtkowiak, T.; Pasieczna, A.; Lukaszewski, Z.; J. Geochem. Explor. 2014, 143, 127.

43. Bonfim, D. B.; Janoni, C. R.; Leite, O. D.; Santos, J. L. O.; Carvalho, L. G.; Rev. Geol. 2016, 29, 195. 
44. Antón, M. A. L.; Spears, D. A.; Somoano, M. D.; Tarazona, M. R. M.; Fuel 2013, 105, 13.

45. Xu, H.; Luo, Y.; Wang, P.; Zhu, J.; Yang, Z.; Water Res. 2019, $165,114981$.

46. Albuquerque, A. C. L. S.; Chaves, H. M. L.; Rev. Bras. Eng. Agríc. Ambient. 2011, 15, 1123.

47. de Freitas, P. L.; Polidoro, J. C.; dos Santos, H. G.; Prado, R. B.; Calderano, S. B.; Gregoris, G.; Manzatto, C. V.; Dowich, I.; Bernardi, A. C. C.; Cad. Geociências 2014, 11, 83, available at https://periodicos.ufba.br/index.php/cadgeoc/article/ view/11795, accessed in January 2021.

48. Fontes, E. O.; Góes, L. M.; Perez Filho, A.; Rev. GEONORTE 2016, 3, 607, available at https://periodicos.ufam.edu.br/index. php/revista-geonorte/article/view/2111, accessed in January 2021.

49. https://biblioteca.ibge.gov.br/visualizacao/periodicos/66/ pam_2018_v45_br_informativo.pdf, accessed in January 2021.

50. Brandão, C. J.; Botelho, M. J. C.; Sato, M. I. Z.; Guia Nacional de Coleta e Preservação de Amostras: Água, Sedimento, Comunidades Aquáticas e Efluentes Líquidos; Agência Nacional de Águas (ANA): Brasília, 2011, available at https:// arquivos.ana.gov.br/institucional/sge/CEDOC/Catalogo/2012/ GuiaNacionalDeColeta.pdf, accessed in January 2021.

51. Jakubowska, M.; Zembrzuski, W.; Lukaszewski, Z.; Talanta 2006, 68, 1736.

52. Santos, J. L. O.; Leite, O. D.; Janoni, C. R.; de Jesus, D. S.; Santos, A. M. P.; Quim. Nova 2017, 40, 989.

53. Silva, A. C.; Torrado, P. V.; Abreu Jr., J. S.; Rev. Univ. Alfenas 1999, 5, 21.

54. Escosteguy, P. A. V.; Galliassi, K.; Ceretta, C. A.; RBCS 2007, $31,247$.

55. Barbosa, J. S. E.; Sabaté, P.; Marinho, M. M.; Rev. Bras. Geociências 2003, 33, 3.

56. Bizzi, L. A.; Schobbenhaus, C.; Vidotti, R. M.; Gonçalves, J. H.; Geologia, Tectônica e Recursos Minerais do Brasil: Texto, Mapas e SIG; CPRM: Brasília, Brazil, 2003, available at http:// www.cprm.gov.br/publique/Recursos-Minerais/Apresentacao/ Livro---Geologia\%2C-Tectonica-e-Recursos-Minerais-doBrasil-3489.html, accessed in January 2021.

57. Roy, S.; Geol. Soc. London, Spec. Publ. 1997, 119, 5.

58. Sampaio, J. A.; da Luz, A. B.; Lins, F. A. F.; Usinas de Beneficiamento de Minérios do Brasil; CETEM/MCT: Rio de Janeiro, Brazil, 2001, available at http://mineralis.cetem.gov. br/handle/cetem/2037, accessed in January 2021.

59. Nygård, T.; Steinnes, E.; Røyset, O.; Water, Air, Soil Pollut. 2012, 223, 699.

60. Stafilov, T.; Šajn, R.; Alijagić, J.; Soil Sediment Contam.: Int. J. 2013, 22, 105.
61. Salminen, R.; de Vos, W.; Tarvainen, T.; Geochemical Atlas of Europe; Geological survey of Finland, 2006, available at http:// weppi.gtk.fi/publ/foregsatlas/, accessed in January 2021.

62. Xiao, T.; Guha, J.; Liu, C.-Q.; Zheng, B.; Wilson, G.; Ning, Z.; He, L.; Appl. Geochem. 2007, 22, 919.

63. Liu, J.; Li, N.; Zhang, W.; Wei, X.; Tsang, D. C. W.; Sun, Y.; Luo, X.; Bao, Z.; Zheng, W.; Wang, J.; Xu, G.; Hou, L.; Chen, Y.; Feng, Y.; Environ. Pollut. 2019, 248, 906.

64. Voegelin, A.; Pfenninger, N.; Petrikis, J.; Majzlan, J.; Plötze, M.; Senn, A.-C.; Mangold, S.; Steininger, R.; Göttlicher, J.; Environ. Sci. Technol. 2015, 49, 5390.

65. Gomez-Gonzalez, M. A.; Garcia-Guinea, J.; Laborda, F.; Garrido, F.; Sci. Total Environ. 2015, 536, 268.

66. Vaněk, A.; Chrastný, V.; Komárek, M.; Penížek, V.; Teper, L.; Cabala, J.; Drábek, O.; J. Geochem. Explor. 2013, 124, 176.

67. Bačeva, K.; Stafilov, T.; Šajn, R.; Tănăselia, C.; Makreski, P.; Environ. Res. 2014, 133, 77.

68. Chen, J.; Wei, F.; Zheng, C.; Wu, Y.; Adriano, D. C.; Water, Air, Soil Pollut. 1991, 57, 699.

69. Vaněk, A.; Chrastný, V.; Mihaljevič, M.; Drahota, P.; Grygar, T.; Komárek, M.; J. Geochem. Explor. 2009, 102, 7.

70. Vaněk, A.; Chrastný, V.; Komárek, M.; Galušková, I.; Drahota, P.; Grygar, T.; Tejnecký, V.; Drábek, O.; J. Hazard. Mater. 2010, 173,717 .

71. Vaněk, A.; Grygar, T.; Chrastný, V.; Tejnecký, V.; Drahota, P.; Komárek, M.; J. Hazard. Mater. 2010, 176, 913.

72. Vaněk, A.; Grösslová,Z.; Mihaljevič, M.; Ettler, V.; Chrastný, V.; Komárek, M.; Tejnecký, V.; Drábek, O.; Penížek, V.; Galušková, I.; Vaněčková, B.; Pavlů, L.; Ash, C.; J. Hazard. Mater. 2015, $283,148$.

73. Vaněk, A.; Grösslová, Z.; Mihaljevič, M.; Trubač, J.; Ettler, V.; Teper, L.; Cabala, J.; Rohovec, J.; Zádorová, T.; Penížek, V.; Pavlů, L.; Holubík, O.; Němeček, K.; Houška, J.; Drábek, O.; Ash, C.; Environ. Sci. Technol. 2016, 50, 9864.

74. https://www.epa.gov/ground-water-and-drinking-water/ national-primary-drinking-water-regulations\#one, accessed in January 2021.

75. Yang, C.; Chen, Y.; Peng, P.; Li, C.; Chang, X.; Xie, C.; Sci. Total Environ. 2005, 341, 159.

76. Yuan-Hui, L.; Geochim. Cosmochim. Acta 1982, 46, 1053.

77. Jia, Y.; Xiao, T.; Zhou, G.; Ning, Z.; Sci. Total Environ. 2013, 450-451, 140.

78. Kaiser, H. F.; Educ. Psychol. Meas. 1960, DOI: 10.1177/001316446002000116.

Submitted: September 23, 2020

Published online: January 26, 2021 